\title{
»On ni bil taka ustvarjalna osebnost «: Kardeljevi spomini na jugoslovanske komuniste, žrtve stalinske politične represije
}

\author{
Lev Centrih \\ UP FHŠ, Oddelek za zgodovino in Inštitut za medkulturne študije \\ lev.centrih@upr.si \\ Inštitut za civilizacijo in kulturo, ICK v Ljubljani
}

\section{Uvod}

Komunistična partija Jugoslavije (KPJ), ali od 1952 Zveza komunistov Jugoslavije (ZKJ), je pravzaprav imela dve zgodovini. Prva, ki je bila daleč najpomembnejša, je bila nerazdružljivo povezana $\mathrm{z}$ narodnoosvobodilnimi boji jugoslovanskih narodov med drugo svetovno vojno. To so bili boji, ki jih je organizirala in vodila KPJ, na njih je vse do druge polovice 8o-ih let utemeljevala svojo oblast. Druga zgodovina KPJ je bistveno presegala ozemlje nekdanje Jugoslavije. Do leta 1943 je bila KPJ namreč sekcija III. komunistične internacionale (kominterne), prve in do zdaj še vedno edine prave globalne politične stranke. Mnoge članice in člani KPJ so zato (vsaj začasno) pristali v vrstah španske, francoske, nemške in sovjetske komunistične partije, njihovo delovanje pa je bilo razpotegnjeno med New Yorkom, Madridom, Parizom, Berlinom, Moskvo, Uralom in Daljnim vzhodom. Rečeno s sodobnim žargonom, zgodovina KPJ/ZKJ je bila hkrati lokalna in globalna.

Spor KPJ z Informbirojem leta 1948 je Jugoslavijo oddaljil od vzhodnega bloka pod gospostvom Sovjetske zveze. Ko je spor v 50-ih letih iz gole obrambe neodvisnosti jugoslovanske države naposled dozorel $v$ alternativni ekonomski in politični model socialistične modernizacije, so se odprla številna vprašanja iz obdobja kominterne. Jugoslovanski ideologi socialistične demokracije in samoupravljanja so novo razvojno pot poskušali utemeljiti na kritiki sovjetske prakse iz 30-ih in 40-ih let. Drugače kot za- 
hodnjaški kritiki stalinizma in/ali totalitarizma pa si zaradi lastne kominternske preteklosti niso mogli privoščiti udobja neprizadetih razsodnikov. Zgodovina mednarodnega delavskega gibanja in Sovjetske zveze je bila v marsičem njihova lastna zgodovina. Pomemben del teh kritik je bilo v 6oih letih oživljanje spomina na mnogoštevilne strankine članice in člane, ki so postali žrtve stalinske represije.

$\mathrm{V}$ pričujočem članku bom pokazal na razliko med jugoslovansko kritiko stalinizma in sovjetsko kritiko »kulta osebnosti«. Težišče bo na Kardeljevi analizi perspektiv socializma 20. stoletja in njegovih spominih na jugoslovanske komuniste, ki so v 30 -ih letih postali žrtve stalinskih čistk. Teza članka je, da je jugoslovanska kritika stalinizma temeljila na kritiki enostrankarskega političnega sistema. Ker pa je Kardelj hkrati priznaval, da se iz objektivnih razlogov ZKJ takemu sistemu ne more povsem in naenkrat odpovedati, je bila jugoslovanska kritika stalinizma $\mathrm{v}$ določeni meri tudi samokritika.

Metoda dela temelji na kritični analizi in kombiniranju primarnih (arhivskih), sekundarnih (idejnopolitičnih - programskih besedil) in znanstvenih virov, ključne izmed njih predstavljam $\mathrm{v}$ prvem delu članka; $\mathrm{v}$ drugem delu analiziram Kardeljevo kritiko enostrankarskega sistema v njegovem razvpitem delu Smeri razvoja političnega sistema socialističnega samoupravljanja (dalje Smeri razvoja) iz 70 -ih let, v tretjem delu pa njegovo nekoliko zgodnejše pričevanje o stalinistični represiji 30-ih let; sledi sklep.

\section{Zgodovinski viri in literatura o jugoslovanski kritiki stalinizma}

Pričujoči članek v veliki meri temelji na obsežnem gradivu, arhivskem viru, ki se kot priloga Informacije, datirane z oktobrom $1968 \mathrm{v}$ Beogradu, nahaja v Arhivu Republike Slovenije, fondu Izvršnega komiteja Centralnega komi-

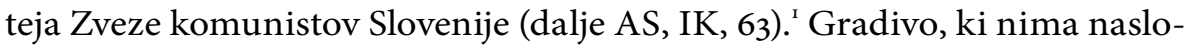
va, je pripravila posebna delovna skupina, ki jo je sestavila Kontrolna komisija CK ZKJ 25. junija 1965. Njena naloga je bila v skladu z odločitvami 8. kongresa ZKJ (1964) zbrati podatke o pozabljenih, toda »znamenitih borcih jugoslovanskega delavskega gibanja« (AS, IK, 63, 1). Gradivo je sestavljeno iz šestih delov in obsega 201 stran: 1 . del vsebuje seznam likvidiranih v ZSSR in rehabilitiranih po Stalinovi smrti; 2. del seznam oseb, ki so bile v ZSSR kaznovane, toda po Stalinovi smrti po sodni in partijski poti rehabi- 
litirane; 3. del je seznam nekaterih oseb, ki so bivale v ZSSR, a so se kasneje vrnile; 4. del je seznam aktivistov KPJ, ki so v ZSSR umrli, padli v Španiji ali na vzhodni fronti med drugo svetovno vojno; 5 . del sestavlja seznam oseb, za katere so takrat sumili, da so v ZSSR preprosto izginile oziroma so v ZSSR prišle kot »antipartijski« ali kot "provokatorski« elementi; v 6. delu so druge nerazporejene osebe. Vsega skupaj je zabeleženih 126 imen, od katerih je bilo $63 \mathrm{v}$ Stalinovem času likvidiranih, prav vsem pa so priložene kratke biografije, pogosto pa tudi opažanja in ocene njihovih sodobnikov. Ti pričevalci so bili znamenite osebnosti, revolucionarji, med katerimi najdemo Velja Vlahovića, Karla Mrazovića, Stevana Belića, Vlajka Begovića in Mihajla Vranoša. Pri zbiranju podatkov je pomagal Miha Marinko, veliko ocen, podatkov in opažanj pa je posredoval tudi Edvard Kardelj, na katerega se bom v nadaljevanju tudi osredotočil. Kardelj je svoje spomine na žrtve stalinske represije podal tudi ob drugih priložnostih. Zanimiv je njegov zapis v zborniku ob Titovi štiridesetletnici vodenja ZKJ. Tam omenja osebnosti, kot so bili Milan Gorkić, Karel Hudomalj in Petko Miletić, vendar so njegova opažanja, v primerjavi z odgovori, ki jih je podal omenjeni delovni skupini, mnogo bolj skopa (Kardelj 1977). Delovna skupina je podatke pridobila še od mnogih institucij, med drugim od Vlade in Vrhovnega sodišča ZSSR, beograjskega Inštituta za preučevanje delavskega gibanja, Zgodovinske komisije in Komisije za mednarodne zveze pri CK ZKJ in CK ZKS. Informacija med drugim navaja, da $\mathrm{k}$ navedenem gradivu spada tudi dodatek, seznam, ki ga je posredoval CK ZKS s podatki o 131 osebah na 147 straneh. Tega dokumenta v imenovanem fondu žal nisem našel. Gradivo iz leta 1968 seveda ne predstavlja izčrpnega seznama jugoslovanskih komunistov in komunistk, ki so $\mathrm{v}$ svoji karieri delovali v Sovjetski zvezi in postali žrtve stalinske represije. Takoj, npr., opazimo, da na seznamih manjka France Klopčič, eden izmed ključnih akterjev jugoslovanskega komunističnega gibanja prve generacije, ki se je po dolgoletnem prestajanju kazni v koncentracijskem taborišču in rehabilitaciji sredi 50-ih let vrnil iz Sovjetske zveze in potem služboval na ljubljanskem Inštitutu za zgodovino delavskega gibanja.

Najizčrpnejša raziskava o ljudeh, ki so izhajali iz ozemlja povojne Jugoslavije in ki so se v letih 1928-1952 znašli v preiskavi ali nemilosti sovjetskega represivnega aparata, je doslej nedokončano in po smrti objavljeno delo srbske zgodovinarke Ubavke Vujošević - Cice. Raziskava zgodovinarke Vujošević ni omejena na komuniste, vsebuje pa 723 imen s kratkimi biografijami, vendar brez (političnih) ocen in opažanj njihovih sodobnikov. 
Po njeni raziskavi, ki temelji na dokumentih raznovrstnih oblastnih in represivnih organov nekdanje sovjetske države in društva Memorial, je bilo v Sovjetski zvezi v letih 1928-1952 ustreljenih 286 Jugoslovanov, 205 samo v letu 1938 (Vujošević 2019, 7-8). To monumentalno delo je po eni strani mogoče brati kot politično grozljivko, po drugi strani pa nam rekonstrukcije biografij ponudijo nepogrešljivi vpogled $\mathrm{v}$ način delovanja mednarodnega komunističnega gibanja kakor tudi vsakdanjega življenja (družbena mobilnost, karierne priložnosti in migrantske poti) povsem običajnih ljudi, ki so se takrat znašli v Sovjetski zvezi.

Pri analizi problematike uporabljam zlasti tri različne sekundarne vire, pri katerih gre za idejnopolitična, programska besedila. Prav pri vseh je v ospredju (mednarodna in lokalna) zgodovina delavskega gibanja in socialističnih držav: véliki projekt Zgodovine Komunistične partije Sovjetske zveze (dalje Zgodovina KPSZ) v šestih zvezkih, pri katerem je sodelovala vrsta sovjetskih zgodovinarjev - akademikov, se je začel v zgodnjih 6o-ih letih na podlagi odločitve CK KPSZ, kot odraz odpravljanja posledic »kulta osebnosti«, ki je terjal prenovljeno zgodovino stranke, hkrati pa je bil usmerjen tudi proti »buržoaznim zgodovinarjem«, ki naj bi po naročilu svojih gospodarjev "grobo potvarjali dejstva (Pospelov 1964, V-LIII). Program ZKJ, sprejet na 7. kongresu ZKJ (1958) v Ljubljani prepleta lokalno in globalno zgodovino KPJ in išče $\mathrm{v}$ njej podlago za samostojno pot Jugoslavije $\mathrm{v}$ socialističnem svetu ter je kot tak v vzhodni Evropi povzročil nemalo jeze (Program ZKJ 1984; Mićunović 1977, 42148). Kardeljeva knjiga Smeri razvoja je prvič izšla leta 1977 (Kardelj 1978). Delo predstavlja mnogo več kot komentar na jugoslovansko ustavo iz leta 1974 in Zakon o združenem delu (1977). Na tihem gre tudi za poskus avtorjevega obračuna $\mathrm{z}$ lastno miselno potjo, ki jo je začel $\mathrm{v}$ zgodnjih tridesetih letih kot mladi komunistični publicist in malo kasneje kot predavatelj na Komunistični univerzi narodnih manjšin Zahoda (KUNMZ) v Moskvi. Smeri razvoja niso lahko branje. Vsiljuje se vtis, da je Kardelj ob vsakem zapisanem stavku tehtal politične posledice doma in na tujem. Drznim in jasnim trditvam prepogosto sledijo povedi, ki izražena stališča omilijo, razvodenijo, včasih celo naravnost negirajo, prepogosti vrinjeni stavki pa otežujejo razumevanje.

Znanstvena publicistika, relevantna za pričujoči članek, je praktično nepregledna. $\mathrm{V}$ zadnjih desetletjih so $\mathrm{v}$ angloameriški akademski skupnosti, ki je na tem področju še vedno vodilna, najprodornejše zgodovinske študije stalinizma in predvojne Sovjetske zveze prispevale raziskovalke in 
raziskovalci, ki so objavljali v zbirki Annals of Communism Series na ameriški univerzi Yale, med katerimi za svojo problematiko posebej izpostavljam monografijo o spopadu znotraj boljševiške partije v 3o-ih letih. Študija ni pomembna le zaradi kritičnih ocen števila žrtev stalinske represije, ki temelji na izčrpnem delu z zgodovinskimi viri, ampak tudi natančne analize boljševiških/stalinskih refleksij o njihovem lastnem početju in razumevanju sveta (Getty in Naumov 1999). Na prostoru nekdanje Jugoslavije je v zadnjih letih na to temo izšla vrsta pomembnih monografij in znanstvenih razprav. Od starejših študij velja omeniti še danes ne povsem preseženega Marjana Britovška, ki so ga zanimali vzroki za poraz Stalinovih nasprotnikov in obotavljivi proces preseganja dediščine stalinizma v času Hruščova (npr. Britovšek 1980). Od najnovejših raziskav izpostavljam dela Avgusta Lešnika, Jožeta Pirjevca in Stefana Gužvice. Raziskave naštetih avtorjev temeljijo na izvirnem in izčrpnem delu $\mathrm{z}$ domačim in tujim arhivskim gradivom, sekundarno ter spominsko literaturo in polemizirajo s starejšimi in najnovejšimi interpretacijami. Lešnik in Pirjevec sta v svojih monografijah zlasti poglobila dosedanja spoznanja o vlogi Jugoslovanov v španski državljanski vojni (npr. Lešnik 2018) in o epizodah iz političnega in intimnega življenja Josipa Broza Tita (npr. Pirjevec 2011). Monografija Gužvice o frakcijskih bojih v KPJ v letih 1936-1940 pa je poleg odkrivanja novih dejstev pomembna tudi v metodološkem pogledu. Avtor je medvojno zgodovino KPJ zastavil kot globalno, kar pomeni, da je dosledno upošteval prepletanje dogodkov in dejanj osebnosti na lokalni in mednarodni ravni. Brez tovrstne zastavitve jugoslovanske kritike stalinizma v času hladne vojne pravzaprav ni mogoče razložiti. Gužvica (2019) v svojem delu poudarja, da frakcijski boji v KPJ niso bili samo jugoslovanska stvar, ampak so vanje posegali tuji komunisti, organi kominterne in celo sovjetske države. Sam v pričujočem članku dodajam, da je bilo jedro jugoslovanske kritike stalinizma $v$ prepričanju, da dogodki v Sovjetski zvezi 30-ih let niso samo stvar in problem te države ter njenega zgodovinskega spomina, ampak mednarodnega delavskega gibanja $v$ celoti in Jugoslavije še posebej. $V$ tem pogledu je ta članek nadaljevanje moje raziskave zgodovine ideoloških aparatov komunističnega gibanja 20. stoletja. V knjigi Marksistična formacija sem zagovarjal tezo, da so Sovjetska zveza in njeni ideološki aparati igrali osrednjo vlogo v mednarodni levici tudi po razpustu kominterne. Ideološko hegemonijo in neposredni vpliv so ti aparati sicer relativno hitro izgubili, so pa ostali pomembni kot referenčne točke kritik in premislekov zgodovine 20. stoletja za številne, praviloma celo med seboj izključujoče se, miselne in 
politične tokove neodvisnih levičarskih skupin, gibanj in strank (Centrih 2011, 64-68).

\section{Enostrankarski politični sistem pri Kardelju}

V drugem zvezku 4. knjige Zgodovine KPSZ je poglavje z naslovom »Zmaga socializma v ZSSR«(Pospelov 1971, 488-532). V njem lahko v glavnem preberemo povzetke dosežkov druge petletke v Sovjetski zvezi (1933-1937): zaključen proces kolektivizacije, krepitev mehaniziranja kmetijstva, nadaljnji razvoj industrializacije, kulturna revolucija, nova ustava (1936). Avtorji posebej poudarjajo razširitev in okrepitev sovjetske - socialistične demokracije, ki naj bi takrat zajela tako ekonomsko kot duhovno sfero družbe. Temeljni pogoj take demokracije je bila po mnenju avtorjev odprava zasebne lastnine nad produkcijskimi sredstvi, zaradi česar je odpadlo "parazitsko prisvajanje rezultatov proizvodnje, utrdila pa se je socialistična delitev, ki temelji na človekovem delu«. Ob tem poudarjajo silni porast ljudskega izobraževanja, ki je dal možnosti za ustvarjalni razvoj slehernega sovjetskega človeka. Razširitev sovjetske demokracije se je nadalje izražala tudi v povečanju aktivnosti organizacij delovnih ljudi, ki jih je vodila Komunistična partija. Npr., leta 1937 je bilo v sindikate včlanjenih 22,2 milijona ljudi, kar je bilo 2,3-krat več kot leta 1926. In ne samo to: $v$ sindikatih so opustil princip kooptacije in uvedli načelo tajnih volitev za vse organe. Sindikati naj bi se poslej pričeli bolj ukvarjati z vprašanji proizvodnje, socialističnega tekmovanja, krepitve socialistične discipline, poboljšanja življenjskih razmer delavcev, sklepali naj bi celo kolektivne pogodbe na ravni podjetij (Pospelov 1971, 503-4). Krono sovjetske demokratizacije je seveda predstavljala ustava iz leta 1936, ki je »za razliko od buržoaznih ustav, ki so omejene samo na formalno priznanje demokratičnih svoboščin, [...] prenesla težišče na zagotavljanje le-teh«. Pri tem je bila v prvi vrsti mišljena osvoboditev delovnih ljudi od kapitalističnega izkoriščanja, od strahu pred brezposelnostjo, revščino itd. Seveda je bila popolnoma zajamčena svoboda vesti, tiska, izražanja in združevanja delovnih ljudi v družbene organizacije - z izjemo vseh tistih dejavnosti, ki bi rušile socializem. Povedano enostavno: demokracija je tukaj v prvi vrsti pomenila boj za izboljšanje socialnega položaja najširših ljudskih množic, ki so »aktivno pritegnjene [...] k neposrednem sodelovanju pri upravljanju z državo in gospodarstvom « (Pospelov 1971, 511, 516). Merili demokratičnosti družbe sta tedaj dve: dvig življenjskega standarda in številčna rast članstva množičnih organizacij, med katerimi ima vodilno mesto Komunistična partija, tj. participacija širokih množic pri različ- 
nih kampanjah, kamor sodi tudi udeležba na volitvah. S takim razumevanjem demokracije so se zadovoljili tudi vodilni jugoslovanski komunisti do začetka 50-ih let, sovjetski ideologi pa vse do konca 80-ih. »Formalna demokracija je postransko vprašanje. Prava demokracija v bistvu samo $\mathrm{s}$ socialno vsebino, « je menil Boris Kidrič konec leta 1945 (Drnovšek 2000, 52).

Poglavje "Zmaga socializma v ZSSR" govori o stabilizaciji in normalizaciji sovjetske družbe po dolgem in težkem obdobju revolucije, državljanske vojne in kolektivizacije. Nekako na sredini tega poglavja pa sledi prav kratek povzetek (vsega slabi dve strani) še nekaterih drugih dogodkov, ki glede na popisovanje vsesplošnega družbenega napredka deluje kot pravo presenečenje:

$V$ sorazmerju $z$ razvojem socialistične graditve se je zagotavljalo tudi učinkovito izvajanje zakonov. Hkrati s slabitvijo partijskega nadzorstva nad organi tožilstev in državne varnosti je prišlo do dejanskih kršitev zakonitosti. Za to je bil v precejšnji meri odgovoren Stalin, ki je imel tedaj veliko polnomočje. (Citat v Britovšek 1980, 262)

Omenjene so žrtve: nedolžni sovjetski državljani, med katerimi so bili komunisti in celo najvidnejši voditelji. CK KPSZ je leta 1956 te pojave označil kot »množične represije«. »Kršitev leninskih načel v življenju partije in države" pa kljub škodi ni mogla "spremeniti narave socialistične družbe«, ker je pod vodstvom CK Partije prišlo do »nadaljevanja demokratizacije sovjetske družbe in odprave dopuščenih napak« (Pospelov 1971, 510).

"Napake« so bile v času pisanja dotične partijske zgodovine v svetu že zelo dobro znane in že dalj časa predmet zgodovinopisja. Del zahodnega zgodovinopisja je véliko čistko v letih 1937-1938, ko je bilo glede na najnovejše raziskave ustreljenih več kot 680.0oo ljudi (Getty in Naumov 1999, 591), interpretiral v skladu s teorijo o totalitarizmu, drugi del pa je raje govoril o stalinizmu kot posebni obliki vladavine in obdobja sovjetske zgodovine (Boffa 1985). Za sovjetske zgodovinarje fenomen stalinizma ni obstajal (Britovšek 1980, 280), namesto tega so govorili o »kultu osebnosti«. Napake po njihovem mnenju niso bile sistemske, ampak subjektivne. Tajno poročilo Hruščova O obsodbi Stalinovega kulta osebnosti, ki ga je za zaprtimi vrati prebral na predvečer 20. kongresu KPSZ 1956, in resolucija CK KPSZ iz junija 1956 kažeta na to, da so "poskušali vse težave iz preteklosti pripisati Stalinu in dogajanje pojasniti z njegovimi značajskimi poteza- 
mi« (Britovšek 1980, 267). Prav zato so sovjetski ideologi brez posebnih težav skovali novi program KPSZ, ki je temeljil na čisti kontinuiteti njihovega delovanja (najmanj) od državljanske vojne (1919) naprej. Program ni predvideval nobenih institucionalnih sprememb in prerazporeditve moči znotraj sovjetske družbe. In v tem pogledu se je bistveno razlikoval od »Programa ZKJ « iz leta 1958, proti kateremu je tudi tiho nastopil. Program KPSZ iz leta 1961 je predvideval ambiciozni načrt izgradnje komunistične družbe v dvajsetih letih. Partijski ideologi so si ta veliki skok v družbenem razvoju prestavljali kot enostavni prehod iz kvantitete $\mathrm{v}$ novo kvaliteto: izpopolnjevanje obstoječega ekonomskega in političnega sistema, $v$ katerega je treba vključiti še širše množice ljudi, bo pripeljalo do »družbenega samoupravljanja«, kar so si predstavljali kot družbo svobodnih in zavednih delovnih ljudi, v kateri je spričo popolnega blagostanja ter izničene razlike med mestom in vasjo, kakor tudi med umskim in fizičnim delom, realizirano načelo »vsakomur po njegovih potrebah« (Gospolitizdat 1961, 62). Cilj jugoslovanskih ideologov je bil načeloma enak. Bistveno pa so se razlikovali v zahtevi, da je mogoče ta cilj doseči samo pod pogojem, da se v obstoječem socializmu marsikaj spremeni. Ali še natančneje: samoupravljanje so zahtevali tukaj in zdaj, kar je zahtevalo radikalne institucionalne spremembe znotraj socialistične države. Njihove zahteve so bile utemeljene s kritičnim pogledom v zgodovino delavskega gibanja.

Ideologi ZKJ so v 50-ih letih načelno sprejeli koncept »kulta osebnosti«, vendar so dodali njegovo sistemsko (»objektivno«) razsežnost, ki se je pri sovjetski razlagi sama po sebi vsiljevala, vendar je kričeče manjkala. Ozadje jugoslovanskih razmišljanj je bilo kajpak vprašanje, kako je bilo mogoče, da sta se sovjetska država in Partija uklonili samovolji enega človeka. Sovjetske razlage so se ustavile pri pojasnjevanju, da so bili ti pojavi v »nasprotju « $\mathrm{z}$ naravo sovjetske družbe tistega časa (Pospelov 1971, 509). Program ZKJ iz leta 1958 pa je trdil precej drugače:

Toda Stalin iz objektivnih in subjektivnih razlogov ni nasprotoval birokratsko-etatističnim tendencam, ki so vznikale iz velike koncentracije oblasti v rokah državnega aparata in iz zraščanja partijskega in državnega aparata, iz enostransko v ospredje stopajočega centralizma. Nasprotno, on sam je postal njihov politični in ideološki nosilec. (ČZDO Komunist 1984, 43)

Stalin torej ni bil preprosto le nekdo, ki je izkoristil veliko zaupanje, ki mu ga je dala Partija, temveč je bil "politični in ideološki nosilec» ten- 
denc, ki so v bistvu obstajale neodvisno od njega in ki so narekovale tudi ne ravno idealne okoliščine graditve socializma. Pri tem je nadvse povedno, da so avtorji Programa ZKJ skoraj dobesedno prevzeli zgoraj že omenjeno uradno sovjetsko trditev, da vsi ti negativni pojavi »niso mogli trajno deformirati in tudi ne trajno zavreti razvoja socializma v Sovjetski zvezi« (ČZDO Komunist, 44). Tega vsekakor niso zapisali zato, da ne bi preveč razjezili voditeljev sovjetske države in Partije. Razlogi so bili bistveno globlji. Jugoslovanski komunisti so pred drugo svetovno vojno $\mathrm{z}$ vsemi sredstvi zagovarjali in "popularizirali« sovjetsko državo (npr. Tito 1968, VIII) in $\mathrm{v}$ silovite frakcijske boje zadnjih let pred vojno, iz katerih je izšel Tito kot zmagovalec, so bili vpleteni številni tuji komunisti pa tudi institucije sovjetske države, ali kot pravi Gužvica (2019, 2-4): »Frakcijski boji niso bili nikoli le notranja zadeva KPJ, čeprav so jih vedno prikazovali kot take.« Po vojni je Jugoslavija dosledneje od vseh »ljudskih demokracij« zvesto sledila sovjetskemu zgledu. Kritika Sovjetske zveze je bila zato vselej v marsičem tudi samokritika lastne prakse. V programu so namreč zapisali, da je bilo v Jugoslaviji zaradi težkih razmer "nujno potrebno, da je vodila aparat oblasti neposredno Komunistična partija. Potrebna je bila visoka stopnja koncentracije politične oblasti v upravnem aparatu.« (ČZDO Komunist 1984, 94)

Jugoslovanski pisci Programa ZKJ so s takimi ocenami zadeli najbolj travmatično jedro komunističnega projekta svoje dobe. Zraščanje državnega aparata in Partije je bilo po njihovi oceni zaradi objektivnih zgodovinskih okoliščin zgodovinska nujnost, po drugi strani pa so hkrati priznali, da so prav iz tega izšle »manifestacije birokratsko-etatističnih tendenc, napak in deformacij v razvoju političnega sistema države " (ČZDO Komunist 1984, 43). Pri tem je potrebno opozoriti, da v Programu $Z K J$ iz leta 1958 izraza »stalinizem« pravzaprav še ne najdemo. Ker so v 50-ih letih ta izraz še vedno najpogosteje uporabljali trockisti, bi se jugoslovanski ideologi z njegovo uporabo $v$ večinskem mednarodnem komunizmu $v$ trenutku popolnoma diskreditirali. Izraz je postal splošno uporaben in zelo popularen $\mathrm{v}$ jugoslovanski politični in znanstveni publicistiki nekoliko kasneje.

Bolj poglobljeno analizo problema razraščanja države in partije je $\mathrm{v}$ svojem delu Smeri razvoja ponudil Edvard Kardelj, ki je šel konec $70-i h$ let v svoji kritiki še nekoliko dlje, ko je poskusil hkrati zavrniti meščanski pluralizem in enostrankarski sistem. Za Kardelja je bil »enopartijski sistem« pravzaprav »izposojen« iz meščanske države, njegove deformacije »z najtežjimi ekscesi « pa so se v sovjetski praksi do skrajnosti izrazile v »stalinizmu«, vendar je hkrati priznal, da si je težko predstavljati, da bi v Sovjetski 
zvezi brez njega izvedli vse družbene spremembe in vzpostavili tiste ekonomske temelje, ki so bili nujni za razvoj socializma. Čeprav je poudaril, da enopartijski sistem ni nujno manj demokratičen od večpartijskega (političnega pluralizma), je dodal, da je tak sistem celo nujno bolj izpostavljen deformacijam, saj v njem prihaja do koncentracije oblasti, ki se lahko "spremeni v orožje tehnobirokratske vladavine nad razredom in družbo.« Avtor takoj v nadaljevanju svojo skoraj predrzno ugotovitev sicer omehča, ko pravi, da tak razvoj ni nujen in da je odvisen od mnogih faktorjev. Temu razmišljanju sledi ugotovitev, ki se nakazuje že v Programu $Z K J$ : »Tudi naša socialistična revolucija je $\mathrm{v}$ prvi fazi v določeni meri vzpostavila enopartijski sistem revolucionarne demokracije, čeprav nikoli v njegovi 'klasični' stalinistični obliki.« (Kardelj 1978, 64-68). Kardelj je šel celo tako daleč, da je priznal, da so »elementi enopartijskega sistema« še vedno navzoči v sistemu oblasti jugoslovanske države, »vendar samo toliko, kolikor jih objektivno narekujejo potrebe varstva revolucije in svobodnega nadaljnjega razvoja socialističnega samoupravljanja« (Kardelj 1978, 66). V praksi je to pomenilo, da je lahko ZKJ ne glede na veljavne zakone in ustavo mobilizirala vse razpoložljive sile in sredstva za obrambo temeljnih pridobitev revolucije. Povedano drugače: »elementi« stalinizma in njegovih potencialnih »deformacij« so še zmeraj obstajali. ${ }^{2}$ Jugoslovanska Partija je razpolagala $\mathrm{z}$ velikansko družbeno in politično močjo in Kardelj je bil realist. ZKJ se po njegovem mnenju oblasti iz »objektivnih razlogov« preprosto ni mogla naenkrat odpovedati. Bistvo njegove zamisli, ki je $\mathrm{v}$ tistem času dobila ime "pluralizem samoupravnih interesov«, je bilo v tem, da je potrebno okoli Partije zasaditi džunglo raznovrstnih institucij - od delavskih svetov $\mathrm{v}$ podjetjih do društev, organizacij in njihovih koordinacij -, v katere bi se postopoma in nadzorovano odlivala njena politična in ekonomska oblast. Država bi »odmrla« na tisti točki, ko bi ZKJ naposled izgubila poslednji nadzor nad vzvodi ekonomske moči in represije ter postala navadni marksistični center, tj. brezzobi možganski trust visoko razvite socialistične družbe (prim. Kardelj 1978, 72). Hkrati bi odpadle poslednje nevarnosti za zlorabo oblasti države - Partije, ki se je po Kardelju najhuje pokazala na primeru stalinizma. Komunizem bi se $\mathrm{v}$ bistvu povrnil k svojim začetkom iz 19. stoletja: ponovno bi postal predvsem intelektualno gibanje. Da je bila taka zamisel za sovjetske ideologe nekaj popolnoma absurdnega, ni potrebno posebej poudarjati. Romantični in pristni utopični moment Kardeljeve vizije gardizma ZKJ/ZKS zapičil natanko v to; glej npr. Hribar 1987 in Urbančič 1987. 
pa je bil slej ko prej v tem, da je prihodnost svoje Partije videl natanko na tistem terenu, ki je bil tudi njemu osebno najbolj všeč in domač, tj. v teoriji in ideologiji.

\section{Kardeljevi spomini na Jugoslovane, ki so izginili}

v stalinskih čistkah

Ivan Timofejević Pavličenko se je rodil leta 1904 v Podgorici. Karlo Mrazović je o njem povedal, da je bil po poklicu najverjetneje delavec - čevljar. Leta 1927 je odšel v Sovjetsko zvezo, kjer se je poročil in postal član boljševiške stranke, dokončal KUNMZ in bil napoten na politično delo v Sverdlovsk in Čeljabinsk - tam je služboval kot učitelj zgodovine. Kot večina drugih Jugoslovanov je bil tudi on aretiran leta 1938. Umrl je leta 1946, najverjetneje v delovnem taborišču ali izgnanstvu, leta 1956 ga je rehabilitiralo Vojaško sodišče Uralskega vojnega okrožja (AS, IK, 63, 64). V monografiji zgodovinarke Vujošević najdemo kar nekaj podobnih primerov družbene mobilnosti, kakršne so se lahko nadejali aktivisti komunističnega gibanja pred drugo svetovno vojno. Mnogi so postali člani partije kot industrijski delavci ali rudarji, kasneje pa so postali poklicni aktivisti ali celo javni uslužbenci sovjetske države. Vse to je bilo v skladu $\mathrm{z}$ duhom časa. Prvo petletko je $\mathrm{v}$ Sovjetski zvezi spremljal program »napredovanj« (vydviženie) za delavce, ki so bili vključeni v razne oblike višjega izobraževanja, da bi zavzeli strokovna in vodilna mesta $\mathrm{v}$ industrijskih podjetjih (Fitzpatrick 2002, 181-84). V našem primeru je šlo za delavce - migrante, ki so si služili kruh v ZDA in zahodni Evropi, kjer so mnogi verjetno sploh prvič prišli v stik s KPJ, preko nje pa jih je pot vodila v Sovjetsko zvezo, sledilo je politično izobraževanje in z njim vsaj potencialno tudi (politična) kariera. Seveda pa to ni bilo nujno. Antun Mavrak, npr., je bil študent prava na zagrebški univerzi in visoki funkcionar KPJ (sredi 20-ih let celo organizacijski sekretar). Leta 1929 je prišel v Moskvo, kjer je delal v Izvršnem komiteju Komunistične internacionale, predavala na KUNMZ, v letih 1930-1931 je deloval v Franciji in Avstriji v zamejskem vodstvu KPJ in nato bil odpoklican nazaj v Moskvo, kjer so ga izključili iz KPJ. Po podatkih iz Informacije in zgodovinarke Vujošević so ga izključili zaradi frakcionaštva, pri čemer dodajam, da se konkretne navedbe iz obeh virov glede njega ne ujemajo povsem. Poslej je delal v tovarni poljedelskih strojev v Rostovu (AS, IK, 63), kasneje pa v moskovski tovarni avtomobilov Stalin (Vujošević). Ustreljen je bil leta 1938, rehabilitiran pa leta 1963 (AS, IK, 63: 70 - 71; Vujošević 2019, 179-80). Anton Prosenc je bil doma iz Škofje Loke ali iz Zagorja, član KPJ od 1924, delal je 
v Franciji in Nemčiji in bil član komunističnih partij obeh držav. Leta 1931 je odšel na delo v Sovjetsko zvezo in rudaril v Kuzbasu. O njegovem študiju ni podatkov. Leta 1937 je bil aretiran, leta 1938 ustreljen, četa 1957 pa rehabilitiran (AS, IK, 63:92; Vujošević 2019, 230). Jože Klenovšek je bil rudar iz Zagorja ali Trbovelj. Kardelj se je o njem spominjal, da je prišel na mednarodno Leninsko šolo v Moskvo leta 1935 ali 1936. Klenovšek je bil po njegovem mnenju krasen revolucionar: »ker je izšel iz neposredne prakse, se je v Leninski šoli posvetil izključno študiju«. Vse kaže, da mu študij ni prinesel posebnega napredovanja. Odšel je v Španijo, kjer se je po Kardeljevi obveščenosti »držal dobro«. Tam je tudi padel (AS, IK, 63,137).

Klenovšek je bil primer zglednega komunista, predanega človeka, ki se je ob revolucionarni praksi strastno posvetil tudi študiju. Kardelju je bilo težje opisovati tiste jugoslovanske komuniste, ki so postali žrtve stalinskih čistk ali pa so od gibanja iz raznovrstnih in tudi ne dovolj pojasnjenih razlogov odpadli. Na splošno si je prizadeval o skoraj vseh osebnostih, ki jih je doletela tragična usoda, povedati vsaj nekaj pozitivnega. Te pozitivne ocene pa so večinoma pospremljene s pokroviteljskimi opazkami, med katerimi izstopa ta, da posameznik »ni bil dovolj ustvarjalna osebnost.« Kaj naj bi ta manko ustvarjalnosti konkretno pomenil, ni najbolj jasno in še najbolj nakazuje avtorjevo zadrego. Tipičen primer je njegovo opisovanje usode Alberta Hlebca, ključnega organizatorja KPJ v Sloveniji v njenem prvem obdobju in delegata KPJ na 6. kongresu kominterne, ki je leta 1939 v ZDA $\mathrm{v}$ nepojasnjenih okoliščinah napravil samomor. Kardelj je o njem povedal:

Ko sem se jaz srečal z njim [1937], je bil že precej demoraliziran z emigracijo in razmerami, ki so vladale v njej in v vrhovih naše partije. Bil je bister in sposoben človek, vendar ne dovolj ustvarjalna figura, da bi se lahko resno upiral vplivom okoliščin, v kakršnih se je razvijalo naše revolucionarno gibanje in katerim tudi ni bil dorasel. Ko je kasneje prišlo do moskovskih procesov, in vsega kar je bilo z njimi povezano, je to Hlebca verjetno do konca demoraliziralo in ga napeljalo, da je napravil samomor. Kot sem slišal, je on $v$ tistem času $v$ Ameriki živel $v$ zelo slabih razmerah in trpel lakoto. (AS, IK, 63, 116)

Tudi Karel Hudomalj po Kardeljevem mnenju ni bil »ustvarjalna osebnost«, čeprav je bil leta 1936 celo organizacijski sekretar KPJ, pomemben akter v frakcijskih bojih znotraj KPJ (Gužvica 2019, 198-200), leta 1939 pa so ga kot »demoralizirani element « iz partije izključili: »Emigracija in frak- 
cionaštvo sta verjetno tudi na njega vplivala negativno, kajti on ni bil taka ustvarjalna osebnost, da bi zmogel razločiti med tistim, kar je prehodno, in tistim, kar je trajno« (AS, IK, 63, 119). Kardelj je nadalje pojasnjeval, da je Hudomalja izkoristil Gorkić, katerega aretacija v Moskvi poleti 1937 je sprožila silovite frakcijske boje v KPJ. »Ko je zaradi Gorkića in skupaj z njim doživel katastrofo, ga je to verjetno do konca demoraliziralo.«O Karlu Hudomalju so v času nastanka tega dokumenta še ugibali, ali je postal gestapovski agent ali je padel $\mathrm{v}$ avstrijskem protifašističnem gibanju. $\mathrm{V}$ resnici je na začetku vojne na Dunaju organiziral odporniško gibanje in leta 1944 končal v Mauthausnu (Dolenc 2010, 238-39).

»Demoraliziranost« je drugo pomembno opažanje, ki ga pogosto zasledimo v Kardeljevih spominih. Nana Šilović je prišla v Sovjetsko zvezo leta 1930, končala KUNMZ, potem delala v tehniki CKKPJ, med vojno je prišla v Jugoslavijo kot oficir Rdeče armade in leta 1946 umrla v prometni nesreči na Dunaju. (Iz biografske zabeležke o njej se vsiljuje vtis, da ni šlo nujno za nesrečo.) Po Kardelju je preko svojega moža, člana CK KPJ Martinovića, v Moskvi sodelovala v frakcijskih bojih znotraj partije. Pri tem je dodal, »da je ona očitno delala za NKVD, kar je samo še en dejavnik več, ki takega človeka pelje v demoralizacijo«(AS, IK, 63, 130).

Sodelovanje s sovjetskim represivnim aparatom, omenjen je NKVD (Ljudski komisariat za notranje zadeve), je po Kardeljevem mnenju pokvarilo komunista. Ljubljančan Franc Čepelnik, sin železničarja, ki so ga zaradi komunističnih aktivnosti izključili iz učiteljišča, je kot osemnajstletni mladenič prišel v Moskvo leta 1926. Na KUNMZ naj bi pripadal »levi« opoziciji, vendar mu to očitno ni takoj škodovalo, ker je leta 1931 postal član boljševiške stranke. Preden so ga poslali nazaj v Jugoslavijo, je bil na političnem delu v Magnitogorsku. Po vrnitvi v Moskvo je bil leta 1938 aretiran in umrl leta $1944 \mathrm{v}$ enem od delovnih taborišč na Kolimi.

Čeprav je bil po naravi dokaj bister mladenič, se je vendarle formiral šele $v$ Moskvi v okoliščinah, ki so takrat vladale tam in $v$ naši partijski emigraciji v letih 1926-1935. Poleg tega mislim - čeprav nisem prepričan, da je bil povezan tudi z NKVD, zaradi česar je ta nekoč dobri skojevec postal bolj funkcionar kot revolucionar. [...] Kljub tem njegovim slabostim on vseeno ni bil sovražnik Partije in socializma, zato je smrtna kazen, ki ga je doletela, po svojem bistvu zločin nad njim tako kot nad drugimi. (AS, IK, 63, 100-1; Vujošević 2019, 49-50) 
Kardelj se ves čas dotika problema »frakcionaštva«, ki se je v KPJ posebej intenzivno razživelo potem, ko je bil leta 1937 v Moskvi aretiran in kasneje tudi likvidiran generalni sekretar Milan Gorkić (Gužvica 2019, 149-51). Toda, kaj je sploh bilo »frakcionaštvo« v komunističnem gibanju? Gužvica pomembno poudarja, da je šlo za stalen in dopusten pojav v levičarskih političnih organizacijah od 19. stoletja naprej, nenazadnje je tudi boljševizem sam nastal iz frakcijskega razkola (Gužvica 2019, 17-20). Lenin je na 10. kongresu boljševiške stranke leta 1921 izsilil prepoved frakcij. V ozadju prepovedi je bil strah, da se bodo začasne grupacije - frakcije slednjič razvile v velike opozicijske bloke, ki bi lahko razbili stranko. Kandidatov za take bloke je bilo vedno več kot dovolj, takrat najizraziteje t. i delavska opozicija. Trocki je malo kasneje to prepoved označil za neumnost oziroma "protislovje«, kot se je korektno izrazil, in zastavil retorično vprašanje: »Kako se izogniti razlikam v mišljenju v partiji, ki šteje pol milijona članov?« (citat v Britovšek 1980, 77) V teoriji naj bi komunisti svoja različna stališča zagovarjali transparentno na partijskih forumih - od celice do kongresa, v zadnji instanci pa bi se morali vselej podrediti volji večine (demokratični centralizem). Toda kaj, če se skupina tovarišev dobi pri nekomu doma na čaju in tam razpravlja o svojih »ločenih mnenjih«? Je tudi to frakcija? Za Trockega je bilo to leta 1923 še smešno, dobrih deset let kasneje pa verjetno le še malokomu. Za ilegalne stranke, kot je bila KPJ, pa je bilo takšno »frakcionaštvo«, sestajanje in razpravljanje $\mathrm{v}$ konspirativnih skupinicah, v resnici pomemben način prakticiranja partijskega življenja, kajti možnosti za široko transparentno razpravljanje in sprejemanje odločitev so imeli pravzaprav bolj malo. Temeljni pogoj za frakcije v KPJ niso bile toliko ambicije njenih posameznih članov niti njihova »ločena mnenja«, ampak golo dejstvo, da je bilo članstvo KPJ v predvojnem obdobju zaradi represije jugoslovanskega kraljevega režima in nalog kominterne raztreseno po vsej Evropi. "Frakcionaštva« je bil lahko v takih okoliščinah upravičeno obsojen prav vsakdo. Natančneje: obsodba frakcionaštva je bila vselej manifestacija politične moči in vpliva. Kot taka je bila v zadnji instanci privilegij zmagovalcev in redkeje poražencev frakcijskih bojev (prim. Gužvica 2019, 17). Tedaj ni čudno, da se kritiki frakcionaštva niso mogli izogniti niti spoštovane osebnosti in prvi voditelji KPJ, kot je bil legendarni Filip Filipović, ki ga je Kardelj spoznal v Moskvi in ki je bil leta 1938 tam tudi ustreljen. O njem je povedal:

Bil je izjemno sposoben in pameten človek, ob tem pa še zelo pošten in skromen. Hkrati pa je bili tipičen intelektualec in najbrž gaje tudi prav to pritegnilo $v$ frakcijske boje. Res pa je, da ni nikoli dajal 
vtisa frakcionaške zadrtosti ali nekega nezdravega odnosa do partije. $(A S, I K, 63,1)$

\section{Sklep}

Kakšna povezava obstaja med Kardeljevimi spomini na žrtve stalinske represije in njegovo nekoliko poznejšo kritiko stalinizma? Na eni strani imamo spomine državnika in funkcionarja na svojo mladost, v katerih igrajo glavno vlogo ljudje, nekatere izmed njih je zelo dobro poznal tudi osebno, na drugi strani pa gre za suhoparno analiziranje razmerij med institucijami, družbenimi razredi, političnimi silami in njihovimi interesi z močnim pridihom utopije. Glavna skupna značilnost obeh razmislekov o preteklosti je dosledno izogibanje črno-belim razlagam. Medtem ko so si sovjetski ideologi in zgodovinarji vse do konca osemdesetih let na vse kriplje prizadevali minimalizirati posledice stalinizma - popolnoma ignorirati jih zaradi težkih posledic pač niso mogli -, je Kardelj najboj travmatična poglavja iz zgodovine mednarodnega komunizma predstavil kot izhodišče za razmislek o njegovi prihodnosti. Najlažje je to napravil na teoretsko-shematski ravni, ko je razraščanje partijskega in državnega aparata pojasnil kot zgodovinsko nujnost, ki je imela hkrati pozitivne in monstruozne posledice. Rešitve ni iskal v premeščanju pozornosti na »dobre« strani enostrankarskega sistema in njegovo neskončno »izboljševanje«, kot so to počeli sovjetski ideologi, ampak v njegovem odpravljanju. Kardelju je bilo težje pojasnjevati okoliščine in vzroke tragedij posameznikov iz njegove mladosti. Ker pa se niti na tej ravni zgodovinskega premisleka ni hotel prepustiti črno-belim sodbam, dobimo iz njegove odkrite pripovedi izjemno brutalno podobo mednarodnega komunizma 30-ih let 20. stoletja. Ta podoba je $\mathrm{v}$ marsičem okrutnejša od tiste, ki nam jo ponuja današnja protikomunistična publicistika. Kardelj niti za hip ne dopušča dvoma, da se komunisti niso borili za pravično stvar socializma, niti takrat, ko so sami postali žrtve socialistične države. Teh žrtev ne poskuša opravičiti z zgodovinsko nujnostjo. Na primeru Franca Čepelnika odkrito pove, da je šlo preprosto za zločin. Komunistična stvarnost je imela $v$ tistem času herojsko in pošastno stran. Boj proti fašiz$\mathrm{mu}$, kulturna revolucija, industrializacija dežele $\mathrm{v}$ nemogočih pogojih na eni strani, na drugi pa represivni aparati države in partije, ki brezobzirno meljejo svoje najboljše ljudi, ki nimajo nikakršnih možnosti, da nanje vplivajo, kaj šele, da bi jih lahko zaustavili. Kardelj to ilustrira na primeru demoralizacije v gibanju. Njegove pokroviteljske opazke o »neustvarjalnosti « posameznikov in njihovi nesposobnosti, da bi »razločili med tistim, kar je 
prehodno, in tistim, kar je trajno « vsiljujejo vtis nelagodja, še bolj pa nezmožnosti, da bi do konca pojasnil, kako je bilo vse to mogoče. Med žrtvami je bil praktično edini skupni imenovalec ta, da so pripadali isti Partiji in mednarodnemu komunističnemu gibanju. Pri Filipoviću namiguje, da se je znašel v težavah tudi zato, ker je bil tipičen »intelektualec«. Toda prav tak »intelektualec « je bil tudi Kardelj sam, ki pa je imel to veliko srečo, da je leta 1937 lahko zapustil Sovjetsko zvezo in se v Sloveniji posvetil ustanavljanju nacionalne komunistične stranke. Poleg tega vélika čistka ni zmlela samo »intelektualcev«, ampak tudi povsem navadne komuniste, kot je bil rudar Anton Prosenc. Žrtvam pravzaprav ni bilo skupno niti to, da so se vsi znašli na napačnem kraju ob napačnem času. Na primeru Hlebca, Šilovićeve in delno tudi Hudomalja vidimo, da so jih posledice vélike čistke tako ali drugače prizadele zunaj Sovjetske zveze.

Prispevek je nastal na podlagi raziskav, sofinanciranih iz programa »Raziskave kulturnih formacij (P6-0278)«, ki ga financira Javna agencija za raziskovalno dejavnost Republike Slovenije.

\section{Viri in literatura}

Arhivski viri

AS, IK, 63: SI, Arhiv Republike Slovenije, AS 1589/IK, CK ZKS, Izvršni komite, t. e. 63, »Informacija«.

\section{Objavljeni viri}

Drnovšek, D. 200o. Zapisniki Politbiroja CK KPS/ZKS 1945-1954. Ljubljana: Arhivsko društvo Slovenije.

Tito, J. Broz. 1968. »Povodom izdavanja Proletera.«V Proleter. Organ Centralnog komiteta Komunističke partije Jugoslavije, 1929-1942, ur. Pero Morača, VII-VIII. Beograd: Institut za izučavanje radničkog pokreta.

\section{Literatura}

Boffa, G. 1985. Fenomen Stalin. Ljubljana: Cankarjeva založba.

Britovšek, M. 1980. Carizem, revolucija, stalinizem, 2. knjiga. Ljubljana: Cankarjeva založba. 
Centrih, L. 2011. Marksistična formacija: zgodovina ideoloških aparatov komunističnega gibanja 20. stoletja. Ljubljana: Založba ${ }^{*} \mathrm{cf}$.

ČZDO Komunist. 1984. Program Zveze komunistov Jugoslavije. Ljubljana: ČZDO Komunist.

Dolenc, E. 2010. Med kulturo in politiko: kulturnopolitična razhajanja v Sloveniji med svetovnima vojnama. Ljubljana: Inštitut za novejšo zgodovino.

Fitzpatrick, S. 2002. Education and Social Mobility in the Soviet Union 19211934. Cambridge: Cambridge University Press.

Getty, A. J., in O. V. Naumov. 1999. The Road to Terror. Stalin and the SelfDestruction of the Bolsheviks, 1932-1939. New Haven, CT; London: Yale University Press.

Gospolitizdat. 1961. Programma Kommunističeskoj partii Sovetskogo Sojuza. Moskva: Politizdat.

Gužvica, S. 2019. Frakcijski boji v Komunistični partiji Jugoslavije med veliko čistko 1936-1940. Ljubljana: Založba Sophia.

Hribar, T. 1987. »Slovenska državnost. Nova revija 6 (57): 3-29.

Kardelj, E. 1977. "Sećanje na dolazak druga Tita na čelo Partije.« V Tito četrdeset godina na čelu SKJ: 1937-1977, ur. Dušan Živković, 49-69. Beograd: Narodna knjiga.

Kardelj, E. 1978. Smeri razvoja političnega sistema socialističnega samoupravljanja, 2. dopolnjena izdaja. Ljubljana: ČZP Komunist.

Lešnik, A. 2018. Rdeča mavrica: delavska socialistična gibanja na razpotjih, 1848-1918-1948. Ljubljana: Znanstvena založba Filozofske fakultete Univerze v Ljubljani.

Mićunović, V. 1977. Moskovske godine 1956-1958. Zagreb: SN Liber.

Pirjevec, J. 2011. Tito in tovariši. Ljubljana: Cankarjeva založba.

Pospelov, P. N., idr., ur. 1964. Istorija kommunističeskoj partii Sovetskogo sojuza, 1. knjiga. Moskva: Izdatel'stvo političeskoj literatury.

Pospelov, P. N., idr., ur. 1971. Istorija kommunističeskoj partii Sovetskogo sojuza, 4. knjiga, 2. zvezek. Moskva: Izdatel’stvo političeskoj literatury.

Urbančič, I. 1987. "Jugoslovanska 'nacionalistična kriza' in Slovenci v perspektivi konca nacije.« Nova revija 6 (57): 30-56.

Vujošević, U. 2019. Nestajali netragom. Jugosloveni - žrtve političke represije $i$ staljinističkih čistki u Sovjetskom Savezu 1927-1953. Beograd: Institut za savremenu istoriju. 


\section{Summary}

"He was not such a creative personality."

Kardelj's memoirs of the Yugoslav communists

- the victims of the Stalinist political repression

The Yugoslav communist movement experienced its key formative period in the 1930s, during the global economic crisis, the rise of fascism, the Spanish Civil War, the development of the Soviet Union, and the severe political repression that took place there. Following the dispute with Cominform (1948), the Yugoslav communists gradually began to evaluate the past period, and part of this project was the revival of the memory of their members who ended up as victims of the Stalinist purges disappearing in the Soviet Union or left the movement because of their disappointment. Some of the most prominent politicians and revolutionaries, including Edvard Kardelj, played an important role in compiling lists and short biographies of communist activists of the 1930s. His comments and observations, recorded in the 196os, convey the traumatic legacy of the Comintern, the factional struggles, and describe the Soviet Union in general. The Yugoslav communists considered themselves the heirs to the October Revolution, but at the same time sought to distance themselves from Lenin's and Stalin's political practices, which was no easy task, since the most important episodes in their history belonged to the Stalin period. In this article, I highlight the difference between the Yugoslav critique of Stalinism and the Soviet critique of the "personality cult ". The article hypothesises that the Yugoslav critique of Stalinism was based on the critique of the single-party political system. However, because Kardelj simultaneously acknowledged that for objective reasons the League of Communists of Yugoslavia could not completely and immediately abolish such a system, the Yugoslav critique of Stalinism was also to some extent a self-criticism. 